\title{
THE COMMONWEALTH ADVISORY COMMITTEE ON DEFENCE SCIENCE
}

\author{
MEETING IN AUSTRALIA
}

$\mathrm{T}$ HE Commonwealth Advisory Committee on Defence Science exists to develop the mutual interest of the countries of the British Commonwealth in defence science. Formal meetings are held at two- to three-year intervals in various member countries. Continuity is given to the work, between meetings, by a permanent Working Party located in London. The Working Party is made up of permanent representatives of member countries and is concerned with reviewing progress and planning for future meetings.

To date, five official meetings have been held in addition to a preliminary informal meeting which was held in 1946. Two of the formal meetings have been held in London, one in India, one in Canada and one recently in Australia.

Meetings are attended by senior officers from the Fighting Services and the Defence Scientific Services of the member countries, and it is an indication of the importance attached to the meetings that officers of the highest status are nominated as delegates.

Credit for the creation of the Commonwealth Advisory Committee on Defence Science rests largely with Sir Henry Tizard, who held a prominent position in defence science in the United Kingdom during the post-war period. One of the first acts of the meeting held recently in Australia was to send him a cable of greeting.

In proposing the preliminary or informal Conference which was held in 1946, the United Kingdom authorities suggested that the Conference might consider the distribution of defence research activities throughout the British Commonwealth so as to make the best possible use of the available and potential facilities and staff in each country. This has continued to be a goal for succeeding Conferences.

One of the decisions of the preliminary meeting in 1946 was that there should be close collaboration with the United States of America in the work of the Committee. Its constitution as a Commonwealth body precluded the United States from becoming a member; but a close association has been maintained, and at all meetings of the Committee American observers have been present by invitation and have made significant contributions to the discussions.

The fifth official meeting of the Committee was held in Australia during the period of October 7-28. It was attended by some sixty delegates, approximately forty of whom were from overseas. Countries represented were Australia, Canada, India, New Zealand, Pakistan, South Africa and the United Kingdom, and in addition, a party of observers from the United States of America attended.

On this occasion Ceylon, the Federation of Rhodesia and Nyasaland, Ghana and Malaya were unable to be represented but are being kept informed of the Conference discussions.

On this occasion the general chairman of the meeting was Sir Leslie Martin, defence scientific adviser and chairman of the Defence Research and
Development Policy Committee in Australia. Delegations, which were comprised of senior representatives of the Fighting Services and the Defence Scientific Services of the member countries, were led by : Australia, Mr. W. A. S. Butement, chief scientist, Department of Supply; Canada, Dr. J. L. Keyston, vice-chairman, Defence Research Board; India, Brigadier Y. B. Gulati, director of weapons and equipment, Army Headquarters; New Zealand, Dr. C. D. Ellyett, Defence Science Advisers Committee; Pakistan, Dr. Mohammed Afaf, senior scientific officer, Defence Ministry; South Africa, Dr. S. Biesheuval, director, National Institute for Personnel Research; United Kingdom, Sir John Carroll, deputy controller, Research and Development, Admiralty; United States (observers), Mr. J. B. Macaulay, deputy assistant secretary, Research and Engineering, Department of Defense.

In planning the meeting, it was considered important that while full opportunity should be given for adequate Conference discussions, there should also be the opportunity for delegates to obtain a broad picture of defence science activities in Australia. This would also provide the occasion to see something of the geography and general development of the country.

To achieve these objectives, the itinerary provided for arrival of delegates in Sydney, the official opening in Canberra, the main business sessions to be held in Melbourne and Adelaide and for visits to be made to places of scientific service and general interest. This itinerary involved some 3,000 miles travel by air and, therefore, introduced problems of organization, but the results were such that the effort was considered well worth while.

The Conference was opened by the Prime Minister of Australia, the Hon. R. G. Menzies, in Canberra on October 7. In his address, Mr. Menzies directed attention to two points which were important in relation to the social implications of defence science. He commented that, because of the glamour attached to the subject at the present time, there was a tendency for the public to think of defence science as being concerned solely with new and revolutionary developments of a most complex character. While much of the work was, of course, of this nature, he as a layman was most impressed in studying the Conference agenda to find that there was still a great deal of research to be carried out on such everyday items as food, clothing and the weather.

The other point which Mr. Menzies commended to delegates was that defence science was being presented to the public in a way which caused them to feel that these very great efforts were being made solely for military purposes and were, therefore, very largely of a destructive character. $\mathrm{He}$ considered that this was far from the truth, and he was of the opinion that there were few defence scientific developments of recent years where the potential application for civil purposes was not of far greater importance than the military application. 
The agenda was made up of some seventy technical papers in addition to the reports of the subcommittees on Service psychology and defence food research and the group on agricultural aspects of defence science. The papers were circulated in advance, and at the Conference they were introduced briefly by named delegates and then discussed by the whole meeting. The papers fell largely in the broad fields covered by the above groups and in the fields of career development, telecommunications, tropical warfare, weapons testing, naval research cold-weather operations, effects of high-level noise and the effects of nuclear weapons. However, in addition, there were many individual papers outside these groups.

The subject of tropical warfare was one of special interest to several of the countries represented, in that their territories embraced large areas of tropical terrain. Numerous papers were discussed, ranging from the effect of the environment on the soldier and his equipment, the need for more efficient vehicles and aircraft for use in tropical areas, mental stress under tropical conditions, navigation and communication in the jungle, clearance of vegetation, corrosion in the tropics, etc.

The weapons-testing theme covered the biggest group of papers discussed at the Conference. The subject was interpreted in its broadest sense, aeroplanes, for example, being treated as weapons. This theme was of great interest to Australia, where two of the major defence science activities, namely, the Woomera Missile Testing Range and the Maralinga Atomic Testing Range, are both concerned very largely with the testing of weapons.

In particular, the Woomera project was discussed in some detail. Numerous papers dealing with the equipment of the Range, various aspects of the trials work and the processing of the results were considered. The discussions were supplemented by a comprehensive visit to Woomera, when the facilities were examined in detail and missile trials were witnessed.

While at Woomera, delegates inspected the missiletracking station which had been established as part of the International Geophysical Year programme.

The visit to Woomera was of particular interest to delegates. The basic conception of this project arose largely from the early discussions by the Commonwealth Advisory Committee on Defence Science, and it was a matter of considerable satisfaction to dele. gates to see the very tangible result that had been produced. Sir John Carroll, leader of the British delegation, in a public address, referred to Woomera as the outstanding example of defence science co-operation in the Free World.

Because of the importance attached to seeing at first hand something of the scientific work proceeding in Australia, several visits were arranged to scientific and appropriate Service establishments. Included in these were the Aeronautical Research Laboratories, the Defence Standards Laboratories, the Weapons Research Establishments at Salisbury and the testing range at Woomera, the Maralinga Atomic Testing Establishments and the Edinburgh and Woomera Royal Air Force Establishments.

Quite apart from these visits, it was felt that it would be of interest for delegates to be given opportunities of seeing something of the country and of work proceeding in other technical fields. For this purpose, a two-day visit was arranged to the Snowy Mountains Scheme in the south-eastern corner of Australia. This is the largest engineering undertaking in Australia, and can compare in magnitude with the largest undertakings in other parts of the world. Although primarily concerned with the conservation of water by means of river diversion and large-scale storage, it is also a major generator of electric power, having a potential capacity of some $2,000,000 \mathrm{~kW}$.

Numerous opportunities were included in the programme to enable delegates to meet Australians in many walks of life. Delegates were honoured by being entertained to lunch by the Government of the Commonwealth and by being received by the Governors of Victoria and South Australia and by the Lord Mayor of Melbourne. In addition to such official functions, several pleasant informal functions including visits to places of interest and private entertainments were arranged-visits to outback sheep stations and to the Andamooka opal fields.

At the close of the Conference, delegates were unanimous that it was one of the most successful held to date. The tangible results are, of course, a series of recommendations arising from three weeks of intensive discussions. These recommendations are for the guidance of member countries; they will be submitted to the respective governments for ratification, when they will become a valuable guide to defence science policies. The other result of the Conference is the intangible one arising from the friendships established between delegates and the mutual appreciation of the special problems faced by member countries.

\section{Lestife Martin}

\section{AUTOMATIC REDUCTION OF GEOPHYSICAL DATA}

$\mathrm{O}$ VER the past two decades there has been a rapid increase in the use of automatic photographic and electronic techniques for recording experimental results. As a result, the number of measurements made need no longer be restricted by fatigue in the experimenter, and sets of results containing millions of measurements are not uncommon. The rate at which results can be accumulated is now so great that the individuals responsible for setting up the equipment can no longer assimilate the information at the rate at which it is produced. This problem can be overcome to some extent by arranging the programme of analysis in such a way that the reduction of data can be dealt with by semi-skilled staff.

Nowadays even this solution is often inadequate. Not only is it difficult to find suitable staff, but also many of the investigations require the analysis of data on a scale so great as to be beyond the capabilities of a team of individuals. The problem is particularly acute in the field of geophysical research, where very large quantities of results are frequently produced in the course of field work of many kinds. 